\title{
IMPLIKASI PERUBAHAN STATUS PENERIMA LISENSI TERHADAP PERJ ANJ IAN LISENSI HAK CIPTA PADA ORGANISASI KSBSI
}

\author{
Irawati ${ }^{1}$, Lailatussafa'ah Indrasrani² \\ Program Studi Magister IImu Hukum \\ Fakultas Hukum Universitas Diponegoro \\ J alan Imam Bardjo, S.H. No. 1-3, Kampus Pleburan, Semarang 50241 \\ ilaindrasrani@gmailcom
}

\begin{abstract}
The absolute right that man possesses over every creation of the human mind is called copyright. One of the copyright disputes is the dispute case of the Konfederasi Serikat Buruh Sejahtera Indonesia (KSBSI) organization logo between Muchtar Pakpahan against Rekson Silaban. In its development the organization undergoes a change of form. SBSI which originally shaped Unitaris into Confederation, it is adjusted with Law no. 21 of 2000 on Trade Unions. The approach method used in this research is the normative juridical legal approach method using descriptive analysis type that describes the prevailing laws and regulations associated with legal theory and practice of the implementation of positive law concerning the problem. In accordance with the development of law in Copyright, the Art of Logo that is used as the Symbol of the Organization has been declared can not be made of Recording of Works as regulated in Article 65 of Law no. 28 years 2014 on Copyright. Should since the SBSI changed its status to KSBSI there must be a new license agreement stating that KSBSI is a channel organization of SBSI, Muchtar and Rekson which at that time still in one umbrella organization also should immediately change the AD / ART SBSI into AD / ART KSBSI which in also explained the history of organization formation until the change of the organization's status.
\end{abstract}

\section{Keywords: Copyright; Organization Logo; Licence Contract; Status Changes.}

\section{ABSTRAK}

Hak mutlak yang dimiliki manusia atas setiap hasil kreasi dari pikiran manusia disebut dengan hak cipta. Salah satu sengketa Hak Cipta yaitu kasus sengketa logo organisasi Konfederasi Serikat Buruh Sejahtera Indonesia (KSBSI) antara Muchtar Pakpahan melawan Rekson Silaban. Dalam perkembangannya organisasi mengalami pergantian bentuk. SBSI yang semula berbentuk Unitaris menjadi Konfederasi, hal tersebut disesuaikan dengan UU No. 21 Tahun 2000 tentang Serikat Pekerja/Buruh. Metode pendekatan yang digunakan dalam penelitian ini adalah metode pendekatan hukum yuridis normatif dengan menggunakan tipe deskriptif analisis yaitu menggambarkan peraturan perundang-undangan yang berlaku dikaitkan dengan teori hukum dan praktek pelaksanaan hukum positif yang menyangkut permasalahan .Sesuai dengan perkembangan hukum dalam Hak Cipta, maka terhadap Seni Logo yang digunakan sebagai Lambang Organisasi, telah dinyatakan tidak dapat dilakukan Pencatatan Ciptaan sebagaimana diatur dalam Pasal 65 Undang-Undang No. 28 tahun 2014 tentang Hak Cipta. Seharusnya sejak SBSI berubah status menjadi KSBSI harus ada perjanjian lisensi baru yang menyatakan bahwa KSBSI adalah organisasi terusan dari SBSI, Muchtar dan Rekson yang pada saat itu masih berada dalam satu payung organisasi juga seharusnya segera merubah AD/ART SBSI menjadi AD/ART KSBSI yang didalam juga dijelaskan sejarah pembentukan organisasi sampai perubahan status organisasi tersebut.

\section{Kata Kunci : Hak Cipta; Logo Organisasi; Perjanjian Lisensi; Perubahan Status.}

\footnotetext{
${ }^{1}$ Dosen Fakultas Hukum Universitas DIponegoro

${ }^{2}$ Mahasiswa Program Studi Magister IImu Hukum Universitas Diponegoro
} 
Jurnal Law Reform

Volume 14, Nomor 2, Tahun 2018

\section{A. PENDAHULUAN}

Manusia itu dikaruniai oleh Tuhan Yang Maha Esa dengan berbagai naluri, bakat, nilai, dan kemampuan untuk hidup menurut pola tertentu. Pola itu dapat berubah - ubah bergantung pada situasi dan kondisi pada suatu waktu dan suatu tempat. Pada suatu waktu manusia itu terdorong untuk mencurahkan isi pikirannya dan isi hati nuraninya dalam bentuk tertentu, misalnya berupa karangan, seni kata, seni musik, seni lukis, seni pahat dan lain - lain. Curahan isi pikiran dan hati nurani yang dituangkan kedalam bentuk karya nyata dinamakan Hak Kekayaan Intelektual. Hak kekayaan intelektual (HKI) adalah suatu sistem yang sekarang ini melekat

Hak Setiap manusia dimuka bumi ini memiliki hak mutlak atas hasil kreasi yang telah diciptakan atau telah mereka wujudkan dalam bentuk barang maupun dalam bentuk ide. Hak mutlak yang dimiliki karena setiap hasil kreasi dari pikiran manusia itulah yang disebut dengan hak cipta.

Konvensi Berne menjadi perjanjian internasional hak cipta yang kemudian diratifikasi ke dalam sistem perundang - undangan Indonesia dengan penetapan Keputusan Presiden No. 18 Tahun 1997 (Keppres No. 18 Tahun 1997), sedangkan perjanjian pembentukan World Trade Organization ( selanjutnya disingkat sebagai WTO) telah diratifikasi dengan UU No.7 Tahun 1994 tentang Pengesahan Agreement on Establishing the World Trade Organization
Program Studi Magister Ilmu Hukum Fakultas Hukum Universitas Diponegoro

(Lembaran Negara Republik Indonesia Tahun 1994 Nomor 57, Tambahan Lembaran Negara Republik Indonesia Nomor 35645). Sebagai Negara yang meratifikasi Konvensi Berne dan perjanjian pembentukan WTO, Indonesia kemudian melakukan pembentukan UU No. 19 Tahun 2002 tentang Hak Cipta. Selanjutnya terdapat konsideran bahwa UU No. 19 Tahun 2002 tentang hak cipta sudah tidak sesuai dengan perkembangan hukum dan kebutuhan masyarakat sehingga perlu diganti dengan undang - undang yang baru. Kemudian pembentukan Undang - Undang baru yaitu UU No. 28 Tahun 2014 tentang Hak Cipta yang berlaku hingga sekarang (Santoso, 2017)

Pengertian hak cipta menurut ketentuan yaang diatur dalam Pasal 1 Ayat (1) UndangUndang Hak Cipta No.28 Tahun 2014 adalah "Hak eksklusif pencipta yang timbul secara otomatis berdasarkan prinsip deklaratif setelah suatu ciptaan diwujudkan dalam bentuk nyata tanpa mengurangi pembatasan sesuai dengan ketentuan peraturan perundang-undangan."

Pengertian hak cipta menurut World Intellectual P roperty O rganization (WIPO) yaitu "copyright is a legal form dicribing right given to creator for the literary and artistic work".

Hak Cipta adalah terminologi hukum yang menggambarkan hak-hak yang diberikan kepada pencipta untuk karya-karya mereka dalam bidang seni,sastra dan IImu Pengetahuan.

Hak Cipta memberikan perlindungan bagi pencipta dalam hubungan pribadi dan intelektual 
dari ciptaannya dan juga untuk memanfaatkan ciptaanya. Hal ini berarti perlindungan Hak Cipta berdimensi Hak Morak (Moral Rights) yang ditimbulkan dari hubungan pribadi dan intelektual pencipta dengan ciptaanya, dan dimensi Hak ekonomi (Economic Rights) terkait dengan pemanfatan atau pengeksploitasian ciptaanya (Jened, 2014).

Ketertarikan akan potensi ekonomi yang tinggi menjadikan seseorang tertarik untuk mendapat manfaat ekonomi dari produk yang dilindungi oleh hak cipta.

Dalam pengeksploitasian ciptaannya, pencipta dapat melakukan sendiri atau dengan memberikan hak kepada orang lain untuk melaksanakan hak ekonominya. Hal inilah yang melandasi adanya kesepakatan antara pencipta dan orang yang berkeinginan dapat hak menikmati hak ekonomi. Kesepakatan antara pencipta dan orang ingin diberi kuasa mendapatkan hak ekonomi dikenal dengan perjanjian lisensi (Lestari, 2013).

Ketentuan yang mengatur mengenai lisensi terdapat pada Pasal 80 sampai dengan Pasal 83 Undang-Undang Hak Cipta yang menyatakan bahwa

"Perjanjian lisensi adalah perjanjian tertulis antara dua pihak atau lebih, yang mana satu pihak yaitu pemegang hak bertindak sebagai pihak yang memberikan lisensi, sedangkan pihak yang lain bertindak sebagai pihak yang menerima lisensi."

Tak jarang konflik timbul akibat dari perjanjian lisensi yang dari waktu ke waktu dapat mengalami perubahan karena hal - hal yang ditimbulkan baik oleh pencipta itu sendiri, pemegang hak cipta maupun pihak lain diluar dari apa yang tertulis dalam perjanjian lisensi. Adanya ketidakjelasan dalam perjanjian lisensi dapat memungkinkan adanya penyalahgunaan hak cipta yang selanjutnya dapat menimbulkan konflik antara pencipta dengan pihak lain baik pemegang hak cipta ataupun pihak yang tidak berhak untuk menggunakan hak cipta tersebut.

Sengketa mengenai siapa pemegang hak cipta dari suatu ciptaan yang terjadi di Indonesia, salah satunya mengenai kasus sengketa logo organisasi Konfederasi Serikat Buruh Sejahtera Indonesia (KSBSI) antara Muchtar Pakpahan dengan Rekson Silaban. Sebelum dilaksanakannya pertemuan tersebut, Muchtar Pakpahan sudah menyiapkan seni gambar logo untuk diajukan dalam pertemuan Buruh Nasional tersebut untuk dijadikan sebagai lambang Organisasi SBSI hingga kemudian gambar logo itu diterima dan ditetapkan menjadi lambang resmi SBSI.

Pada kongres keempat (IV), para peserta kongres memutuskan untuk merubah bentuk organisasi yang sebelumnya berbentuk organisasi Unitaris menjadi Konfederasi atau Dewan Pengurus Pusat Konfederasi Serikat Buruh Sejahtera Indonesia (DPP KSBSI) yang merupakan organisasi payung, memiliki 11 (sebelah) Federasi Serikat Buruh. Adanya perubahan inilah yang membuat perjanjian lisensi antara pencipta dan pemegang lisensi menjadi 
tidak jelas, karena pencipta menganggap ia menyerahkan lisensi hak cipta kepada SBSI bukan KSBSI.

Berdasarkan latar belakang diatas, maka penulis tertarik untuk meneliti dan mengkaji lebih dalam mengenai "IMPLIKASI PERUBAHAN STATUS PENERIMA LISENSI DALAM PERJANJIAN LISENSI HAK CIPTA dengan mengambil contoh pada Kasus Putusan Mahkamah Agung Nomor 378K/Pdt.Sus HKI/2015)". Permasalahan yang diangkat yaitu Apakah setiap perubahan status penerima lisensi membawa implikasi terhadap keberlanjutan perjanjian lisensi hak cipta, serta bagaimana pengaruh perubahan status Serikat Buruh Sejahtera Indonesia menjadi Konfederasi Serikat Buruh Sejahtera Indonesia (KSBSI) terhadap Perjanjian Lisensi Hak Cipta yang diberikan oleh Muchtar Pakpahan selaku Licensor .

Dalam Black's Law Dictionary lisensi diartikan sebagai

"The Permission by competent authority to do an act which, without such permission would be illegal,a trespass,a tort, or otherwise would not allowable."

dengan rumusan tersebut dapat disimpulkan bahwa lisensi dalam pengertian yang lebih lanjut melibatkan suatu bentuk perjanjian tertulis dari pemberi lisensi dan penerima lisensi. Perjanjian ini sekaligus berfungsi sebagai bukti pemberian izin dari pemberi lisensi kepada penerima lisensi untuk menggunakan nama dagang, paten, Cipta atau hak milik lainnya (Hak Kekayaan Intelektual) (Widjaja, 2001).Pemberian hak untuk memanfaat kan Hak Atas Kekayaan Intelektual ini disertai dengan Imbalan dalam bentuk pembayaran Royalti oleh penerima lisensi kepada penerima lisensi.

Selanjutnya, dalam membuat perjanjian lisensi dinyatakan sah apabila telah memenuhi asas-asas perjanjian. Salah satu asas perjanjian yang penting untuk dikaji yaitu asas kebebasan berkontrak. Asas kebebasan berkontrak merupakan asas kebebasan yang seluas-luasnya oleh undang-undang diberikan kepada masyarakat untuk mengadakan perjanjian tentang apa saja, sesuai dengan peraturan perundangundangan. Kebebasan berkontrak termuat dalam Pasal 1338 KUHPerdata menjelaskan bahwa:

Semua perjanjian yang dibuat secara sah berlaku sebagai undangundang bagi mereka yang membuatnya. Suatu perjanjian tidak dapat ditarik kembali selain dengan sepakat kedua belah pihak, atau karena alasan-alasan yang oleh undangundang dinyatakan cukup untuk itu. Suatu perjanjian harus dilaksanakan dengan itikad baik.

Kata "semua" berarti meliputi seluruh perjanjian, baik yang dikenal maupun yang tidak dikenal undang-undang. Kebebasan berkontrak adalah salah satu asas yang sangat penting dalam hukum perjanjian, yang merupakan kehendak bebas dari pancaran Hak Asasi Manusia. Asas kebebasan berkontrak ini mempunyai hubungan erat dengan isi perjanjian, yaitu kebebasan untuk menentukan "apa" dan "dengan siapa" perjanjian itu diadakan (Sjahdeini, 1993). 
Kebebasan berkontrak baik bagi individu dalam mengembangkan diri baik di dalam kehidupan pribadi maupun kehidupan sosial kemasyarakatan, sehingga beberapa pakar menegaskan kebebasan berkontrak merupakan bagian dari hak asasi manusia yang dihormati (Sjahdeini,1993).

Unsur-unsur asas kebebasan berkontrak, antara lain: Kebebasan untuk membuat atau tidak membuat perjanjian, Kebebasan untuk memilih dengan siapa akan membuat perjanjian, Kebebasan untuk menetapkan bentuk perjanjian,Kebebasan untuk menetapkan isi perjanjian, dan e) Kebebasan untuk menetapkan cara membuat perjanjian.

Kelima unsur asas kebebasan berkontrak termuat dalam isi perjanjian lisensi, maka antara pemberi dan penerima linsensi dapat terlindungi secara hukum.

\section{B. METODE PENELITIAN}

Metode pendekatan yang digunakan dalam penelitian ini adalah metode pendekatan hukum yuridis normatif. Penelitian hukum normatif atau penelitian hukum doktrinal, adalah penelitian hukum yang mempergunakan sumber data sekunder (Soemitro, 1988).

Pendekatan yang digunakan yaitu pendekatan Peraturan Perundang- Undangan (Statute Approach) Pendekatan ini dilakukan terhadap peraturan perundang-undangan yang mengatur terkait dengan hak cipta, yakni UndangUndang Dasar 1945, Undang-Undang Nomor 19 tahun 2002 tentang Hak Cipta, dan UndangUndang Nomor 28 tahun 2014 tentang Hak Cipta.
Pendekatan Konseptual (Conceptual Approach). Pendekatan ini dilakukan jika pendekatan perundang-undangan tidak secara lengkap mengatur mengenai permasalahan yang dibahas dalam penelitian ini (Marzuki, 2007) .

Spesifikasi penelitian ini menggunakan tipe deskriptif analisis yaitu menggambarkan peraturan perundang-undangan yang berlaku dikaitkan dengan teori hukum dan praktek pelaksanaan hukum positif yang menyangkut permasalahan di atas (Soemitro, 1988 ).

\section{HASIL PENELITIAN DAN PEMBAHASAN}

\section{Perlindungan Hukum Terhadap Pemegang} Hak Cipta Logo Dengan Perubahan Status

\section{Penerima Lisensi}

Intellectual property rights atau hak kekayaan intelektual memiliki ciri khas yakni bernilai komersial dan merupakan hak pribadi yang dapat dilisensikan dan merupakan hak monopoli guna mencegah orang lain menggunakannya secara tanpa izin (Purwaningsih, 2005). Orang selain pencipta dapat menikmati hak tersebut dari seorang pencipta dengan cara pengalihan hak cipta. Pasal 16 ayat (Undang - Undang Hak Cipta menyatakan bahwa :

"Hak cipta dapat beralih atau dialihkan, baik seluruh maupun sebagian karena pewarisan; hibah; wakaf; wasiat; perjanjian tertulis; atau sebab lain yang dibenarkan sesuai dengan ketentuan peraturan perundang-undangan." 
Pemberian izin penggunaan karya dapat dilakukan salah satunya melalui pemberian lisensi kepada pihak lain.

Berdasarkan Pasal 1 angka (20) Undang Undang Hak Cipta yang dimaksud dengan Lisensi adalah izin tertulis yang diberikan oleh Pemegang Hak Cipta atau Pemilik Hak Terkait kepada pihak lain untuk melaksanakan hak ekonomi atas Ciptaannya atau produk Hak Terkait dengan syarat tertentu.

Dengan dilakukannya lisensi, maka pemegang hak cipta berhak untuk mendapatkan royalty dari si penerima lisensi kecuali diperjanjikan lain. Jumlah royalty yang wajib dibayarkan kepada pemegang Hak Cipta oleh penerima lisensi adalah berdasarkan kesepakatan kedua belah pihak dengan berpedoman kepada kesepakatan organisasi profesi (Gumanti, 2016).

Logo masuk dalam kualifikasi ciptaan, akan tetapi tidak dapat dicatatkan di Ditjen Hak Kekayaan Inteletual Kementrian Hukum dan HAM .Pengaturan tersebut mereduksi perlindungan hukum bagi pemegang hak cipta logo, karena tidak ada pencatatan terkait dengan siapa pemegang hak cipta logo pertama. Tidak tercatatnya logo tersebut tentu mempunyai akibat hukum kesulitan penentuan siapa yang berhak atas ciptaan logo tersebut .

Dalam contoh kasus Logo SBSI yang merupakan bentuk pemikiran pribadi Muchtar Pakpahan dan para pendiri organisasi SBSI yang sebagian besar merupakan prakarsa Muchtar
Pakpahan sendiri yang pada saat itu merasakan pentingnya keberadaan suatu logo dari organisasi yang hendak dibuatnya (pada saat itu bernama Serikat Buruh Sejahtera Indonesia / SBSI). Namun Logo yang dihasilkan oleh Muktar Pakpahan ini tidak dilakukan pendaftaran ke Dirjen HKI Departemen Hukum dan HAM.

Suatu ciptaan harus mempunyai keaslian (nilai orisinalitas) untuk seorang pencipta dapat menikmati hak-hak yang diberikan undangundang. Unsur keaslian ini sangat erat hubungannya dengan bentuk perwujudan suatu ciptaan. Oleh karena itu, suatu ciptaan baru dapat dianggap asli jika bentuk perwujudannya bukanlah merupakan jiplakan (plagiat) dari ciptaan lain yang telah diwujudkan sebelumnya. Suatu ciptaan, mempunyai hak cipta jika ciptaan yang bersangkutan diwujudkan dalam bentuk tulisan atau bentuk material yang lain. Hal ini berarti bahwa suatu ide yang tidak diwujudkan dan hanya berupa ide saja belum dapat dikatakan sebagai suatu ciptaan dan belum dilindungi oleh hak cipta.

Persyaratan Hak Cipta Logo berupa nilai orisinalitas Milik Muchtar Pakpahan muncul sejak Logo tersebut selesai diciptakan, dipertontonkan, dan disetujui oleh seluruh peserta dalam kongres saat itu meskipun Muchtar belum melakukan pendaftaran.

Untuk menyeimbangkan kepentingan individu dengan kepentingan masyarakat, Menurut Sunaryati Hartono, ada 4 prinsip dalam sistem HKI dimana salah satunya adalah Prinsip 
Sosial. Berdasarkan prinsip ini, sistem HKI memberikan perlindungan kepada pencipta tidak hanya untuk memenuhi kepentingan individu, persekutuan atau kesatuan itu saja melainkan berdasarkan keseimbangan individu dan masyarakat. Bentuk keseimbangan ini dapat dilihat pada ketentuan fungsi sosial dan lisensi wajib dalam undang - undang hak cipta Indonesia. Jadi sistem HKI memberikan perlindungan kepada Muchtar Pakpahan Selaku Pencipta. Muchtar Pakpahan tetap memiliki Hak Eksklusif yaitu berupa hak moral dan hak ekonomi, namun berdasarkan prinsip ini Muchtar Pakpahan masih memperhatikan nasib para buruh dan melepaskan hak ekonominya untuk diberikan kepada organisasi SBSI. Yang dapat beralih atau dialihkan hanya hak ekonomi saja, sedangkan hak moral tetap melekat pada diri penciptanya. SBSI hanya memiliki hak ekonomi saja, sedangkan hak moral tetap melekat pada Muchtar Pakpahan. Pengalihan hak cipta ini harus dilakukan secara jelas dan tertulis baik dengan atau tanpa akta notaris yang kemudian disebut sebagai perjanjian lisensi.

Pelaksanaan perjanjian lisensi mensyaratkan baik pemberi lisensi maupun penerima lisensi harus melaksanakan prestasinya secara seimbang. Jika perjanjian lisensi Hak Cipta dibuat dengan tujuan penyalahgunaan hak eksklusif Hak Cipta perjanjian itu dapat dibatalkan berdasarkan prinsip umum hukum perjanjian.

Berdasarkan prinsip - prinsip perjanjian bahwa apabila terdapat perubahan pada obyek atau subyek perjanjian seharusnya perjanjian yang lama dapat ditambahkan klausula perbarahuan atau perubahan obyek yang dilekatkan pada perjanjian. Dapat pula perjanjian dibatalkan dan digantikan dengan perjanjian yang baru. Jika tidak dilakukan perubahan dala perjanjian lisensi, maka dapat dinyatakan sebagai suatu bentuk penyalahgunaan karena ketidaksesuaian dari segi subyek ataupun obyek perjanjian.

Penyalahgunaan tersebut pada umumnya dikaitkan dengan tidak dipenuhinya salah satu syarat sahnya perjanjian sebagaimana diatur dalam Pasal 1320 BW. Pasal tersebut mengatur mengenai syarat sahnya perjanjian yang meliputi:

a. kesepakatan untuk mengikatkan diri;

b. kecakapan untuk membuat perjanjian;

c. objek tertentu; dan

d. kausa sebagai tujuan yang diperbolehkan oleh hukum.

Syarat yang dilanggar berkenaan dengan penyalahgunaan keadaan adalah syarat kesepakatan karena dianggap tidak adanya pernyataan kehendak yang bebas ketika memberikan kesepakatan. Untuk itu, menurut Rahmi Jened yang dituliskan oleh Agung Jatmiko menyatakan bahwa pihak yang dirugikan dapat mengajukan pembatalan bilamana ia tidak dapat menghendaki perjanjian tersebut dan yang bersangkutan harus membuktikan (Sujatmiko, 2010).

Hal ini berarti semenjak SBSI berubah menjadi KSBSI maka perjanjian lisensi dari 
Jurnal Law Reform

Volume 14, Nomor 2, Tahun 2018

Muchtar Pakpahan kepada SBSI harus diubah sesuai dengan perubahan status organisasi tersebut. Dikarenakan logo yang berupa gambar hasil ciptaan Muchtar Pakpahan identik dengan struktur organisasi SBSI.

Sehingga dapat dikatakan bahwa Muchtar Pakpahan, adalah pencipta dan pemegang hak cipta dari suatu ciptaan yang berupa karya seni yang dijadikan logo dari suatu organisasi yaitu Konfederasi Serikat Buruh Sejahtera Indonesia (KSBI). Sementara itu, tanpa sepengetahuan Muchtar Pakpahan, Rekson Silaban sebagai Ketua Umum KSBI telah mendaftarkan logo KSBI tersebut kepada Dirjen HKI pada Tahun 2004 sebagai pencipta dan pemegang hak cipta dari logo tersebut, sehingga ia telah mendapatkan sejumlah keuntungan dari penggunaan logo tersebut.Artinya Rekson Silaban mendaftarkan logo tersebut dengan itikad tidak baik dengan tujuan mengambil keuntungan komersial. Hal ini mengakibatkan Muchtar Pakpahan kehilangan hak ekonomi atas logo yang digunakan oleh KBSI tersebut.Karena terbukti dengan logo yang digunakan, KBSI mendapat sejumlah aliran dana dari Internasional yang jumlahnya tidak sedikit. Artinya dalam hal ini KBSI tidak lagi menggunakan logo milik Muchtar untuk kepentingan sosial tetapi juga komersial. Artinya sudah ada perbuatan yang melanggar kesepakatan yang sudah antara SBSI (sebelum berubah menjadi KBSI) dengan Muchtar Pakpahan.
Program Studi Magister Ilmu Hukum Fakultas Hukum Universitas Diponegoro

Ciptaan logo dalam konteks pengaturan Pasal 65 Undang - Undang No. 28 tahun 2014 berpotensi menimbulkan banyak sengketa. Hal ini juga terjadi dalam kasus logo antara Muchtar dengan KSBSI (semula SBSI).

Sesuai dengan asas - asas umum dalam perjanjian.bahwa setiap perjanjian dapat mengacu pada beberapa asas yaitu :

1. Asas Kebebasan Berkontrak

2. Asas Konsensualisme

3. Asas Personalia

4. Asas Itikad Baik

Perubahan Identitas para pihak dalam suatu perjanjian tidak mutlak menjadikan Perjanjian Itu Batal, asalkan memang klausula dalam perjanjian itu tetap disepakati dan sah menurut hukum. Dalam praktek perjanjian, apabila terdapatnya perubahan identitas maka perjanjian itu bisa diperbaiki, diubah khususnya terhadap Identitas para pihak, tentunya dengan suatu anggapan bahwa para pihak tetap sah dan cakap dalam melakukan tindakan hukum sesuai isi perjanjian.

Namun apabila memang Muchtar Pakpahan selaku pencipta dari karya cipta Logo memberikan lisensinya hanya kepada SBSI, dan kemudian terjadi perubahan status seperti yang telah diuraikan diatas merasa antara SBSI dan KSBSI adalah organisasi yang berbeda maka sudah seharusnya perjanjian lisensi antara Muchtar Pakpahan dengan organisasi tersebut dibatalkan dan dibuat perjanjian lisensi yang baru. 
Dengan menyesuaikan dengan asas - asas umum dalam melakukan perjanjian .

2. Pengaruh perubahan status Serikat Buruh Sejahtera Indonesia menjadi Konfederasi Serikat Buruh Sejahtera Indonesia (KSBSI) terhadap Perjanjian Lisensi Hak Cipta yang diberikan oleh Muchtar Pakpahan selaku Licensor

\subsection{Implikasi Perubahan Status penerima} lisensi terhadap Pemberi lisensi

Hak cipta dari segi fungsi merupakan legalitas kepemilikan hak ekslusif dari suatu ciptaan. Legalitas ini memberikan perlindungan hukum pada ciptaan tersebut dan menjamin hakhak dari pencipta tidak dilanggar, sehingga ciptaan yang telah dilindungi tidak akan disalahgunakan oleh pihak lain (Haryawan \& Akasih, 2016).

KSBSI adalah organisasi yang berbeda dengan SBSI. Sehingga tidak ada perjanjian lisensi antara Muchtar Pakpahan dengan KSBSI. Hal ini membuat organisasi KSBSI tidak berhak menggunakan logo SBSI apalagi untuk keperluan komersial. Namun fakta menyatakan bahwa KSBSI mendapatkan dana dari luar negeri dan tidak memberikan royalti apapun kepada pencipta .Hal ini tentu merugikan Muchtar Pakpahan sebagai pemilik hak cipta yang sah baik secara moril maupun materiil.

Seharusnya KSBSI yang tetap menggunakan logo SBSI melaksanakan kewajibannya kepada Muchtar berupa pembayaran Royalti sesuai dengan yang telah disepakati di dalam perjanjian lisensi.Dengan ini artinya Muchtar sebagai pencipta logo tidak menerima Hak ekonomi atas karya ciptanya.

Begitu juga dengan beralihnya struktur organisasi SBSI yang semula unitaris berubah menjadi Konfederasi, juga mengakibatkan perubahan pada nama organisasi. Hal ini juga dapat menghalangi hak Muchtar sebagai pemilik logo sekaligus pemberi lisensi untuk menerima manfaat ekonomi dari KSBSI.

Hal ini dapat terjadi karena subyek di dalam perjanjian lisensi secara tertulis antara Muchtar Pakpahan dengan SBSI. Seperti halnya yang diatur dalam Pasal 1320 KUHPerdata yaitu adanya kesepakatan para pihak.

Dalam hal ini belum ada kesepakatan dari Muchtar sebagai pemberi lisensi untuk menerima perubahan status SBSI yang berubah menjadi KSBSI.

Sehingga perjanjian lisensi tersebut dapat dibatalkan karena tidak lagi memenuhi unsur subyektif. Hal inilah yang menghalangi Muchtar Pakpahan untuk memperoleh hak ekonomi berupa royalti karena pihak penerima lisensi adalah SBSI dan bukan KSBSI.

Jika kita telaah lebih lanjut, Dalam perkembangan Hak Kekayaan Intelektual (HKI) saat ini telah diberlakukannya Undang-Undang Hak Cipta baru yaitu Undang-undang No. 28 Tahun 2014 Tentang Hak Cipta yang disahkan pada tanggal 16 Oktober 2014 menggantikan Undang-undang Hak Cipta sebelumnya yaitu Undang-undang No. 19 Tahun 2002. Sedangkan 
kasus antara Muchtar Pakpahan dengan KSBSI bergulir dan baru diputus pada tahun 2015, pertimbangan Hakim Mahkamah Agung telah mengacu pada Undang - Undang No 28 Tahun 2014 tentang Hak Cipta, yaitu bahwa logo merupakan suatu karya cipta yang tidak dapat dilakukan pencatatan.

Hal ini sesuai dengan yang tertuang dalam Pasal 65 Undang - Undang Hak Cipta yang menyatakan bahwa

"Pencatatan Ciptaan tidak dapat dilakukan
terhadap seni lukis yang berupa logo atau
tanda pembeda yang digunakan sebagai
merek dalam perdagangan barang/jasa
atau digunakan sebagai lambang
organisasi,badan usaha,atau badan
hukum."

Berdasarkan ketentuan pada Pasal diatas ,maka terhadap suatu logo yang didaftarkan termasuk sebagai merek dan bukan karya cipta .Sehingga pendaftaran logo di Dirjen HKI atas karya cipta logo SBSI yang dilakukan oleh Rekson Silaban pada Tahun 2004 tidak dapat dijadikan sebagai bukti bahwa Rekson adalah Pemilik karya cipta logo yang sah.

\subsection{Implikasi Perubahan Status Organisasi}

\section{Terhadap Penerima Lisensi}

SBSI sebagai pihak yang diberi ijin dalam perjanjian lisensi dapat terus menggunakan logo sebagaimana yang telah diperjanjikan sesuai dengan batas waktu yang telah ditentukan. Namun dengan berubahnya status SBSI menjadi KSBSI ,apabila tidak dilakukan pembaharuan perjanjian lisensi ,maka dapat dianggap oleh pemberi lisensi bahwa KSBSI tidak lagi berhak menggunakan logo SBSI.

Karena nama subyek yang telah dituliskan sebagai pihak penerima lisensi dan berhak atas penggunaan logo adalah SBSI dan bukan KSBSI,sehingga dapat dianggap KSBSI bukan pihak yang dapat menggunakan logo tersebut secara sah. Tentunya hal ini melanggar Hak Ekonomi Muchtar Pakpahan sebagaimana yang tertuang dalam Pasal 9 ayat (2),(3) yaitu :

"Setiap orang yang melaksanakan hak ekonomi pencipta wajib mendapatkan ijin dari Pencipta atau pemegang hak cipta."

"setiap orang yang tanpa izin pencipta atau pemegang hak cipta dilarang melakukan penggandaan ddan/atau penggunaan secara komersial ciptaan."

Oleh karena itu KSBSI yang merupakan organisasi yang telah dibesarkan oleh Muchtar Pakpahan dkk itu menghentikan perbuatannya yaitu mempergunakan Logo, Nama, Mars, dan Tri Darma Serikat Buruh Sejahtera Indonesia (SBSI).

Sebagai dasar bagi Muchtar dalam mengajukan gugatan ganti rugi terhadap KSBSI terhadap penggunaan logo yaitu Pasal 99 Undang - Undang Hak Cipta yang menyatakan bahwa pencipta, pemegang hak cipta berhak memperoleh ganti rugi kepada pengadilan Niaga atas pelanggaran Hak cipta dan Hak Terkait, serta pencipta atau pemegang hak dapat memohonkan putusan sela agar perbuatan penggunaan logo SBSI oleh KSBSI dapat dihentikan selama menunggu putusan yang berkekuatan hukum tetap. 
2.3 Implikasi Perubahan Status Penerima Lisensi Terhadap Perjanjian Lisensi Yang Telah Dibuat Sebelumnya

Sebagaimana yang telah dibahas didalam bab sebelumnya, perjanjian Lisensi pada dasarnya adalah perjanjian. Seperti halnya perjanjian pada umumnya, maka perjanjian lisensi juga tunduk pada ketentuan perjanjian yang berlaku didalam Kitab Undang-undang Hukum Perdata di Indonesia. Ada beberapa asas yang berlaku didalam perjanjian di Indonesia yaitu :

a. Asas kebebasan berkontrak. Asas kebebasan berkontrak memberikan kebebasan yang sangat luas kepada individu untuk mengatur hak dan kewajiban para pihak didalam suatu perjanjian (Putranti, 2015). Ini artinya para pihak bebas membuat kontrak dan mengatur sendiri isi kontrak tersebut, sepanjang memenuhi kriteria syarat sebagai kontrak; Tidak dilarang oleh undang-undang; Sesuai dengan kebebasan yang berlaku; dan Sepanjang kontrak tersebut dilaksanakan dengan iktikad baik (Rumerung, 2014).

b. Asas konsensualisme. Asas ini tertuang didalam Pasal 1320 ayat (1) KUHPerdata. Asas konsensualisme ini berarti bahwa pada asasnya suatu perjanjian, timbul sejak detik tercapainya konsensus atau kesepakatan antara kedua pihak yang melakukan perjanjian. Asas konsensualisme ini tercermin dari unsur pertama pada Pasal 1320 KUHPerdata yang mengatur tentang syarat sahnya perjanjian. yaitu "sepakat mereka yang mengikatkan diri (Putranti, 2015).

c. Asas Pacta Sunt Servanda

Semua perjanjian yang dibuat secara sah adalah berlaku sebagai undang-undang bagi yang membuatnya. Bahwa perjanjian lisensi yang dibuat oleh para pihak digunakan sebagai acuan bagi mereka dalam melaksanakan kewajiban penerima kepada pemberi lisensi, dalam hal ini adalah ijin penggunaan logo dan pembayaran royalti.

d. Asas Personalitas

Asas Personalitas tertuang didalam Pasal 1315 KUHPerdata .Asas personalitas ini dapat diterjemahkan sebagai asas kepribadian, yang berarti bahwa pada umumnya tidak seorang pun dapat mengadakan perjanjian kecuali untuk dirinya sendiri.Sudah sewajarnya suatu perjanjian hanya mengikat bagi pihak-pihak yang mengadakan perjanjian itu, dan tidak mengikat pihak yang tidak terlibat dalam perjanjian itu (Putranti, 2015).

e. Asas Itikiad Baik

Asas Iktikad baik tertuang didalam Pasal 1338 ayat (3) KUHPerdata. Asas ini dapat diartikan bahwa para pihak didalam perjanjian Lisensi wajib melaksanakannya dengan itikad baik tanpa ada unsur sengaja maupun lalai dalam pelaksanaan perjanjian.

Dalam Sengketa perjanjian lisensi antara KSBSI dengan Muchtar Pakpahan telah memperoleh Putusan Mahkamah Agung yang berkekuatan hukum tetap. Hakim telah 
mempertimbangkan ketentuan sebagaimana yang mengatur tentang Hak Cipta khsuusnya logo dan asas - asas umum perjanjian dalam memberikan putusannya terhadap Sengketa Muchtar Pakpahan dengan KSBSI.

Hakim Mahkamah Agung menilai bahwa dengan struktur organisasi baru sebagai konfederasi,maka KSBSI tidak lagi boleh menggunakan logo SBSI milik Muchtar Pakpahan.

Melalui putusan Mahkamah Agung Nomor 378K/Pdt.Sus-HKI/2015 dinyatakan bahwa KSBSI adalah organisasi terusan dari SBSI, Muchtar dan Rekson yang pada saat itu masih berada dalam satu organisasi juga seharusnya segera merubah Perjanjian lisensi terkait pada perubahan pada penerima lisensi dan AD/ART SBSI menjadi AD/ART KSBSI yang didalamnya juga dijelaskan sejarah pembentukan organisasi hingga terjadi perubahan status organisasi tersebut.

Dengan tidak dilakukannya perubahan pada perjanjian serta AD/ART SBSI menjadi KSBSI,maka perjanjian lisensi tersebut menjadi batal.

Namun pada tahun 2012 Muchtar Pakpahan mengundurkan diri dan dari KSBSI lalu mendirikan Serikat Buruh yang bernama Serikat Buruh Sejahtera Indonesia (SBSI) sendiri dan menggunakan logo, nama, Mars SBSI, Tridarma SBSI yang digunakan oleh KSBSI. Hal ini tidak akan terjadi jika pada tahun 2003 ada perbaharuan perjanjian lisensi dan AD/ART SBSI menjadi KSBSI.

\section{SIMPULAN}

1. Sejalan dengan hak cipta sebagai hak eksklusif dan hak ekonomi, pihak penciptal pemegang hak cipta mempunyai hak untuk memberi izin atau melarang pihak lain untuk melaksanakan hak ekonomi atas ciptaannya dan pemberian izin tersebut tidak diperkenankan untuk merugikan Pencipta. Sistem HKI memberikan perlindungan kepada Muchtar Pakpahan Selaku Pencipta. Muchtar Pakpahan sebagai pencipta tetap berhak atas Hak ekonomi dari pemanfaatan logo baik yang digunakan oleh SBSI maupun setelah berubah menjadi KSBSI. Meskipun pihak KSBI ,Rekson Silaban sudah melakukan pendaftaran terhadap logo di Depkumham pada Tahun 2004, namun tidak menimbulkan hak bagi Rekson Silaban sebagai pemilik karya cipta logo yang sah.

Pada dasarnya penulis sudah setuju dengan pertimbangan Majelis Hakim mengenai kasus di atas, dimana Majelis Hakim akhirnya mengabulkan gugatan dari Muchtar Pakpahan. Namun, mempertimbangkan pembelaan dari Tergugat, yaitu Rekson Silaban yang menyatakan bahwa logo tersebut adalah milik bersama, milik organisasi sehingga tidak dapat dimiliki oleh satu orang, patut diperhatikan, karena menyangkut kepentingan pengakuan dan kesejahteraan para buruh di Indonesia. 
Muchtar Pakpahan tidak sepakat bahwa penerima lisensi yaitu KSBSI adalah organisasi yang sama dengan SBSI. Sejak tahun 2012 dimana Muchtar Pakpahan memutuskan untuk keluar dari KSBSI dan membentuk organisasi SBSI baru, perjanjian lisensi yang dibuat sebelumnya seluruhnya seolah tak pernah ada.

2. Berdasarkan prinsip - prinsip perjanjian bahwa apabila terdapat perubahan pada obyek atau subyek perjanjian seharusnya perjanjian yang lama dapat diatalkan dan digantikan dengan perjanjian yang baru. Hal ini berarti semenjak SBSI berubah menjadi KSBSI maka perjanjian lisensi dari Muchtar Pakpahan kepada SBSI harus diubah sesuai dengan perubahan status organisasi tersebut juga terhadap AD/ART dari KBSI. Dengan mengingat Seni Logo SBSI adalah merupakan "LAMBANG ORGANISASI" yang telah lama digunakan oleh organisasi SBSI, maka berdasarkan Pasal 65 Undang-Undang No. 28 tahun 2014 tentang Hak Cipta, tentunya terhadap Seni Logo SBSI tersebut seharusnya tidak dapat dilakukan Pencatatan Ciptaan, namun demikian Seni Logo "SBSI" tersebut telah terlanjur didaftarkan dan tercatat dalam Daftar Umum Ciptaan atas nama Muchtar Pakpahan, sehingga oleh karenanya harus dibatalkan dan dicoret dari Daftar Umum Ciptaan yang terdaftar. Dengan demikian, dalam proses pembuktian di pengadilan, hakim tidak boleh menjadikan pendaftaran sebagai salah satu alat bukti yang harus ada agar seseorang dapat dinyatakan sebagai pencipta. Hakim tidak boleh beranggapan bahwa pemegang hak cipta yang sah adalah yang terbukti telah mendaftarkan ciptaan, dan orang yang tidak memiliki bukti pendaftaran tidak diakui sebagai pencipta. Hakim harus mempertimbangkan bukti-bukti yang lain untuk menentukan pencipta yang sah atas suatu ciptaan. Secara hukum Rekson Silaban dan KSBSI sebagai sebuah Perkumpulan dan atau Badan Hukum memiliki harus mengganti logo "SBSI" dengan logo yang sesuai dengan bentuk organisasi KSBSI, karena terbukti menggunakan logo suatu organisasi buruh yang tidak sesuai dengan nama dan bentuk organisasi tersebut.

\section{DAFTAR PUSTAKA}

\section{Buku}

Jened, R. (2014). Hukum Hak Cipta (Copyrights Law). Bandung : PT.Citra Aditya Bhakti.

Marzuki, Peter M. (2007). Penelitian Hukum . Malang : Kencana.

Purwaningsih, E. (2005). Perkembangan Hukum Intellectual Preoperty Rights. Bogor : Ghalia Indonesia.

Sjahdeini, Sutan R. (1993). Kebebsan Berkontrak dan Perlindungan yang seimbang bagi Para Pihak dalam Perjanjian Kredit Bank Indonesia (Buku I). Jakarta : Institut Bankir Indonesia. 
Jurnal Law Reform

Volume 14, Nomor 2, Tahun 2018

Soemitro, Ronny H. (1988). Metodologi Penelitian Hukum dan Jurimetri. Jakarta : Ghalia Indonesia.

Widjaja, G. (2001). Lisensi (Seri Hukum Bisnis) . Jakarta : PT.Raja Grafindo Persada.

\section{J urnal}

Haryawan, Aditya., \& Akasih, Putri Y D. (2016) Perjanjian Lisensi Hak Cipta Di Indonesia. Bussines Law Review Vol.01, pp.32-47.

Santoso, Djoko Hadi, \& Sujatmiko, Agung.. (2017). Royalti Hak Cipta Sebagai Obyek Jaminan Fidusia. Masalah - Masalah Hukum, Jili 46 (No.3) , pp.198 - 204.

Lestari, Hesty D. (2013). Kepemilikan Hak Cipta Dalam Perjanjian Lisensi (Kajian Putusan Mahkamah Agung Nomor 104 PK/PDT.SUS/2011). J urnal Yudisial Vol.6 No.2, pp.173 - 188.

Gumanti, R. (2016). Perjanjian Lisensi di Indonesia. Al-Mizan Vol.12 No.1, pp.245 260.

Rumerung, C. (2014). Surat Perjanjian Lisensi Terhadap Pemegang Hak Cipta Kepada Pihak Lain. Lex Privatum,Vo.II (No.1),pp. 17 - 26.

Sujatmiko, A. (2010). Peran dan Arti Penting Perjanjian Lisensi Dalam Melindungi Merek Terkenal. Mimbar Hukum Vol.22 (No.1), pp.114-126.

Putranti, D. (2015). Pembatasan Perjanjian Lisensi Hak Atas Kekayaan Intelektual
Program Studi Magister Ilmu Hukum Fakultas Hukum Universitas Diponegoro dalam Hukum Persaingan Usaha. J urnal Yuridis, Vol 2, (No.1), pp.43 -61.

\section{Peraturan Perundang - Undangan}

Kitab Undang - Undang Hukum Perdata Undang - Undang No.19 Tahun 2002 tentang Hak Cipta

Undang - Undang No.28 Tahun 2014 Tentang Hak Cipta 